\title{
MENGGALI POTENSI ASET WISATA KREATIF DI KAWASAN PETILASAN KERATON KARTASURA
}

\author{
Shofna Koesninda \\ Prodi Arsitektur Fakultas Teknik \\ Universitas Muhammadiyah Surakarta \\ e-mail: shoefna2032@gmail.com
}

\author{
Alpha Febela Priyatmono \\ Prodi Arsitektur Fakultas Teknik \\ Universitas Muhammadiyah Surakarta \\ e-mail: alpha febela@ums.ac.id
}

\begin{abstract}
ABSTRAK
Kartasura memiliki sejarah yang tidak banyak diketahui orang, karena seiring berjalannya waktu sejarah Kartasura semakin pudar. Sejarah tersebut memiliki keterkaitan yang sangat erat dengan keberadaan Keraton Kartasura, yang sangat minim diketahui publik. Keraton Kartasura merupakan asal mula sejarah berdirinya Keraton Surakarta. Namun, saat ini bangunan keraton tersebut sudah tidak ada, hanya tersisa petilasannya saja dan sekarang menjadi makam tokoh bersejarah dan makam kerabat keraton. Meskipun hanya tersisa bekasnya saja, keraton ini merupakan bangunan bersejarah dan sampai pada akhirnya dijadikan sebagai bangunan cagar budaya oleh pemerintah, dan telah disahkan berdasarkan undang-undang. Rasa kepedulian masyarakat sekitar terhadap bangunan tersebut mulai hilang, sehingga perlu adanya upaya untuk menggali potensi-potensi yang ada di kompleks keraton dan kawasan sekitar sebagai proses pengembangan wisata agar dapat dikenal oleh masyarakat luas. Penelitian ini bertujuan untuk mengidentifikasi potensi apa saja yang terdapat di kompleks keraton dan kawasan sekitar. Metode yang digunakan yaitu gabungan kuantitatif kualitatif deskriptif dengan penekanan pada observasi, wawancara, dan kuesioner. Hasil penelitian ini yaitu tergalinya potensi-potensi di kompleks keraton dan kawasan sekitar yang dapat dikembangkan serta terungkapnya alasan dibalik tidak dapat berkembang menjadi tempat wisata sampai saat ini. Berdasarkan indikator yang digunakan, masih terdapat potensi yang belum berkembang dan yang menjadi kendala utama yaitu faktor ekonomi atau biaya.
\end{abstract}

KATA KUNCI: Keraton Kartasura, kawasan sekitar, potensi, wisata

\section{PENDAHULUAN}

\section{Latar Belakang}

Kartasura ambil bagian dalam sejarah singkat hingga ditetapkannya sebuah situs cagar budaya di daerah tersebut. Sejarah singkat yang dimaksudkan tersebut merupakan sebuah tempat berdirinya Keraton Kartasura, yang sejarahnya sangat minim diketahui publik. Kompleks Keraton Kartasura berada di Dusun II Ngadirejo Kecamatan Kartasura Kabupaten Sukoharjo. Berada di sebelah selatan Pasar Kartasura.

Keraton Kartasura merupakan bagian dari sejarah berdirinya Keraton Surakarta atau dikenal dengan Keraton Kasunanan Surakarta (Lampah, 2017). Namun, saat ini bangunan utamanya sudah tidak ada, hanya tersisa petilasan dan beberapa rumah di dalam kompleks keraton. Meskipun hanya tersisa bekasnya saja, kompleks keraton termasuk situs bersejarah hingga ditetapkan sebagai cagar budaya yang dilindungi oleh Undang Undang Nomor 11 tahun 2010 tentang cagar budaya. Rasa kepedulian masyarakat sekitar terhadap situs bersejarah tersebut tampaknya mulai pudar dan hilang. Kondisi fisik petilasan keraton saat ini sangat memprihatinkan, itulah yang menyebabkan Keraton Kartasura menjadi sangat jarang terekspos.

Kondisi tersebut menarik untuk diteliti dan digali, terutama kajian mengenai potensi-potensi yang kemungkinan ada dan dapat dikembangkan sebagai potensi wisata, termasuk di dalamnya mengkaji kendala-kendala yang menjadi menghambat dalam perkembangannya. Hambatan dapat juga berupa belum ditemukannya potensi yang sebetulnya dapat dikembangkan. Sangat diharapkan hasil penelitian nantinya dapat menjadikan Keraton Kartasura dikenal oleh masyarakat luas dengan nilai historisnya yang tinggi sebagai asset wisata, dan dapat mendorong berbagai pihak untuk memaksimalkan situs Keraton Kartasura sebagai asset wisata yang bersejarah di Kartasura.

\section{TINJAUAN PUSTAKA}

\section{Sejarah}

Berikut merupakan pengertian sejarah menurut beberapa ahli: 
1. Menurut Herodotus, sejarah adalah sesuatu yang berputar seperti lingkaran dimana tinggi rendahnya dipengaruhi oleh keadaan manusia, bukan sesuatu yang perkembangannya ke arah depan yang memiliki tujuan pasti.

2. Menurut Ibnu Khaldun, sejarah adalah sebuah catatan yang berisi tentang perubahanperubahan yang telah terjadi pada sifat/karakter manusia di dunia.

3. Menurut J.V. Bryce, sejarah adalah sebuah catatan yang berisi tentang sesuatu yang telah dipertimbangkan, dibicarakan, serta dilakukan oleh manusia.

\section{Artefak sebagai Objek Sejarah}

Artefak merupakan benda-benda bersejarah peninggalan masa lampau yang diciptakan atau dimodifikasi oleh makhluk hidup serta dapat dialihtempatkan. Sedangkan artefak bisa dikategorikan sebagai objek sejarah apabila sebuah peninggalan bersejarah memiliki bentuk-bentuk arsitektural, seperti gedung atau bangunan kuno, sculpture, ataupun taman-taman yang masih tetap terjaga dalam kurun waktu yang lama juga telah melalui suatu peristiwa di masa lampau.

\section{Cagar Budaya}

Berdasarkan UU Cagar Budaya No. 11 Tahun 2010, Cagar Budaya adalah sebuah asset budaya berupa benda, bangunan, struktur, dan kawasan. Cagar budaya di berbagai tempat keberadaannya sangat dianjurkan untuk dilestarikan karena mempunyai poin penting bagi sejarah, ilmu pengetahuan, pendidikan, agama, dan/atau kebudayaan, karena melewati prosedur pengesahan (pemberian status cagar budaya oleh pemerintah kabupaten/kota sesuai usulan dari tim ahli cagar budaya).

\section{Kriteria Cagar Budaya}

(1) Berumur 50 Tahun atau bahkan lebih, (2) Mewakili masa gaya paling singkat berumur 50 tahun, (3) Memiliki makna spesial bagi sejarah, ilmu pengetahuan, pendidikan, agama, atau kebudayaan, (4) memiliki nilai budaya bagi penguatan kePenulisan.

\section{Benda Cagar Budaya}

Jenis cagar budaya kategori benda cagar budaya, yaitu berupa benda alam atau benda buatan yang difungsikan oleh makhluk hidup, sisa sisa biota yang dapat dikaitkan dengan aktivitas atau sejarah manusia, bersifat bergerak atau tidak, serta menggambarkan suatu kesatuan atau gabungan.

\section{Bangunan Cagar Budaya}

Merupakan gabungan beberapa komponen yang tercipta dari benda alam atau buatan manusia untuk melengkapi kebutuhan ruang berdinding atau tidak berdinding, dan beratap.

\section{Struktur Cagar Budaya}

Suatu cagar budaya yang memiliki unsur satu atau jamak, dan separuh atau semuanya melebur dengan alam.

\section{Situs Cagar Budaya}

Suatu cagar budaya yang memiliki unsur benda, bangunan, atau struktur cagar budaya, dan memiliki informasi terkait kegiatan manusia di masa silam.

\section{Kawasan Cagar Budaya}

Sekelompok ruang yang letaknya berdekatan dengan dua situs cagar atau lebih, dan terdapat produk ciptaan manusia berupa lansekap budaya yang telah berumur lebih dari 50 tahun. Kawasan cagar budaya dapat menunjukkan fungsi ruang dalam berbagai pola yang berumur minimal 50 tahun, dan dalam proses pemanfaatan ruang berskala luas tersebut dapat memperlihatkan pengaruh manusia masa silam. Kawasan cagar budaya dapat memberikan bukti terbentuknya lansekap budaya, dan mempunyai lapisan tanah yang di dalamnya memendam bukti kegiatan manusia atau endapan fosil.

\section{Potensi dan Kawasan Wisata}

Potensi wisata adalah suatu sumber daya yang tersebar di berbagai tempat yang dapat ditingkatkan menjadi suatu wisata. Dalam definisi lain, potensi wisata merupakan suatu kemampuan yang dimiliki berbagai daerah untuk berkembang menjadi suatu atraksi wisata dengan tidak melupakan aspek-aspek lainnya sebab berpengaruh terhadap kepentingan ekonomi (Pendit, 2003).

\section{Wista Kreatif}

Wisata kreatif merupakan suatu interaksi yang terjadi antara masyarakat sekitar dengan para wisatawan di objek wisata/daya tarik wisata yang dikunjungi. Wisata kreatif juga mendukung ekonomi kreatif. Ooi (2006) mengatakan bahwa ekonomi kreatif dan sektor wisata merupakan dua hal yang saling berpengaruh dan bersinergi apabila dapat dikelola dengan baik.

\section{Pengertian Objek dan Kawasan Wisata}

Objek wisata merupakan seluruh objek yang mampu menarik perhatian wisatawan lokal maupun asing untuk mengunjunginya, baik berupa alam, bangunan sejarah, kebudayaan, ataupun pusat-pusat rekreasi modern. Berikut merupakan pengertian objek wisata menurut beberapa sumber :

1. Peraturan Pemerintah No.24/1979.

Objek wisata adalah hasil nyata dari ciptaan manusia, tata hidup, seni budaya, sejarah bangsa serta 
tempat atau keadaan alam yang memiliki daya pikat untuk didatangi oleh wisatawan lokal maupun asing.

2. Surat Keputusan Departemen Pariwisata, Pos, dan Telekomunikasi No.KM 98/PW:102/MPPT87.

Obyek wisata adalah sumber daya wisata yang dimiliki suatu tempat atau keadaan alam dimana tujuan pembangunan dan pengembangannya untuk menarik perhatian wisatawan lokal maupun asing dan antusias mengunjunginya.

Yoeti (1996) mengatakan bahwa suatu daerah apabila memiliki keinginan untuk menjadi sebuah tempat tujuan wisata yang apik juga menarik untuk dikunjungi, harus mengembangkan beberapa hal berikut, yaitu :

1. Terdapat sesuatu yang dapat dilihat (something to see)

Adanya sesuatu yang menarik untuk dilihat, objek wisata memiliki keunikan/ciri khas tersendiri yang berbeda dengan objek wisata lain.

2. Terdapat sesuatu yang dapat dibeli (something to buy)

Adanya sesuatu yang menarik untuk dibeli, bisa berupa sesuatu yang khas dari daerah tersebut yang dapat dijadikan cinderamata untuk dibawa pulang oleh pengunjung. Hal ini berkaitan dengan ekonomi kreatif dimana suatu daerah wisata dapat menciptakan produk inovatif daerahnya sendiri.

3. Terdapat sesuatu yang dapat dilakukan (something to do)

Adanya aktivitas yang dapat dilakukan atau dikerjakan di tempat wisata tersebut sehingga dapat menciptakan suasana nyaman dan membuat pengunjung kerasan di tempat tersebut.

Beberapa pengertian mengenai objek wisata yang telah dijabarkan di atas, dan dapat disimpulkan bahwa sebuah kawasan wisata merupakan suatu daerah yang memiliki tempat cukup luas yang di dalamnya terdapat objek wisata, dimana objek wisata tersebut didukung oleh keindahan alamnya serta fasilitas pelengkap sehingga wisatawan akan melirik dan merasa tertarik untuk berkunjung.

\section{Pariwisata}

Pariwisata berasal dari bahasa Sansekerta, pari berarti berulang-ulang dan wisata berarti suatu perjalanan. Pariwisata merupakan suatu kunjungan ke satu destinasi menuju destinasi lain dan dilakukan secara berulang-ulang. Sedangkan menurut UU Nomor 9 Tahun 1990, wisata adalah suatu kegiatan atau perjalanan yang bersifat sementara, untuk menikmati obyek/daya tarik wisata dan dilakukan secara sukarela.

\section{Komponen Sarana dan Prasarana Pariwisata}

Konsep pariwisata atau konsep 4A menurut James Spillane (dalam Herlina, 2016) terdiri atas:

\section{Atraksi}

Atraksi merupakan suatu objek wisata yang memiliki daya tarik sehingga dapat memicu wisatawan terpikat untuk mendatangi tempat wisata tersebut.

2. Aksesibilitas

Aksesibilitas merupakan sarana yang mempermudah wisatawan untuk menjangkau tempat tujuan wisata.

\section{Amenitas}

Amenitas merupakan fasilitas pendukung yang terdapat di luar daerah tujuan wisata dan bertujuan untuk memberikan kenyamanan kepada wisatawan.

\section{Aktivitas}

Aktivitas merupakan segala kegiatan yang ada di daerah tujuan wisata serta dapat dilakukan oleh wisatawan.

Tabel 1 menunjukkan konsep wisata yang dapat diindikasikan oleh beberapa komponen terkait:

Table 1. Konsep dan Indikator Pariwisata (4A)

\begin{tabular}{ll}
\hline Konsep 4A & Indikator \\
\hline \multirow{2}{*}{ Atraksi } & Keindahan \\
& Budaya \\
& Peninggalan bersejarah \\
& Sarana permainan dan hiburan \\
& Kondisi jalan \\
& Transportasi \\
& Papan petunjuk arah \\
& Penginapan \\
& Gereja \\
& Pondok setengah terbuka \\
Aksesibilitas & Restoran/warung \\
& Tempat parker \\
& MCK \\
Amenitas & Jasa angkut \\
& Jasa komunikasi \\
& Jasa pemandu wisata \\
& Pos keamanan \\
& Area pejalan kaki \\
& Pemerintah \\
& Swasta \\
& Masyarakat \\
\hline
\end{tabular}

Sumber: (Herlina, 2015)

\section{METODE PENELITIAN}

Pada penelitian ini menggunakan metode gabungan kualitatif dan kuantitatif deskriptif. Metode ini akan menghasilkan suatu gambaran/penjelasan mengenai keadaan objek yang diteliti. Kedua metode dapat saling melengkapi satu sama lain (Sugiyono, 2009).

\section{Variabel Penelitian}

\section{Undang-Undang}

Kriteria suatu objek maupun sebuah tempat bisa dijadikan sebagai cagar budaya tercantum dalam UU Cagar Budaya No. 11 Tahun 2010.

2. Indikator Penelltian 
Dalam pengumpulan data menggunakan indikator untuk mempermudah pengelompokan data yang dihasilkan, seperti tercantum dalam Tabel 2.

Table 2. Indikator Penelitian

\begin{tabular}{|c|c|}
\hline Indikator Potensi & Uraian \\
\hline Sejarah & $\begin{array}{l}\text { Situs Bersejarah } \\
\text { Suatu tempat atau objek yang } \\
\text { dapat dikategorikan sebagai } \\
\text { peninggalan sejarah. }\end{array}$ \\
\hline $\begin{array}{l}\text { Bangunan dan } \\
\text { Lingkungan Buatan }\end{array}$ & $\begin{array}{l}\text { a. Rumah Tinggal } \\
\text { Rumah-rumah yang memilki ciri } \\
\text { khas/keunikan berdasar tipe } \\
\text { bangunan zaman dahulu. } \\
\text { b. Open space antar rumah } \\
\text { Suatu ruang terbuka yang } \\
\text { dibangun berbagai fasilitas } \\
\text { seperti seating group, dan lain- } \\
\text { lain. }\end{array}$ \\
\hline $\begin{array}{l}\text { Tradisi Sosial- } \\
\text { Budaya }\end{array}$ & $\begin{array}{l}\text { Suatu tradisi/kegiatan yang } \\
\text { berkaitan dengan aktivitas social } \\
\text { dan dilakukan secara rutin tiap } \\
\text { hari-hari tertentu. }\end{array}$ \\
\hline $\begin{array}{l}\text { Tradisi Seni } \\
\text { (Pertunjukan) } \\
\text { Budaya }\end{array}$ & $\begin{array}{l}\text { Suatu tradisi/kegiatan yang } \\
\text { berkaitan dengan kesenian dan } \\
\text { dilakukan untuk dipertunjukkan. }\end{array}$ \\
\hline Home Industry & $\begin{array}{l}\text { Kegiatan ekonomi yang berpusat di } \\
\text { rumah dengan berbagai macam } \\
\text { jenis usaha. }\end{array}$ \\
\hline
\end{tabular}

Sumber: (Wawancara dengan Febela, 2019-Ketua

Komunitas Kampung Batik Laweyan)

\section{Fokus Penelitian}

Wilayah Keraton Kartasura dan sekitarnya berada di lingkup Kelurahan Kartasura. Wilayah ini cukup luas karena kawasan keraton pada zaman dahulu tersebar ke berbagai tempat. Namun, setelah keraton mengalami kehancuran dan hanya tersisa bekasnya saja menjadikan kawasan sekitar berubah menjadi sebuah kampung. Berdasarkan kondisi tersebut, maka penelitian ini hanya berpusat pada Keraton Kartasura dan kawasan sekitar dalam jangkauan radius sejauh 100 meter.

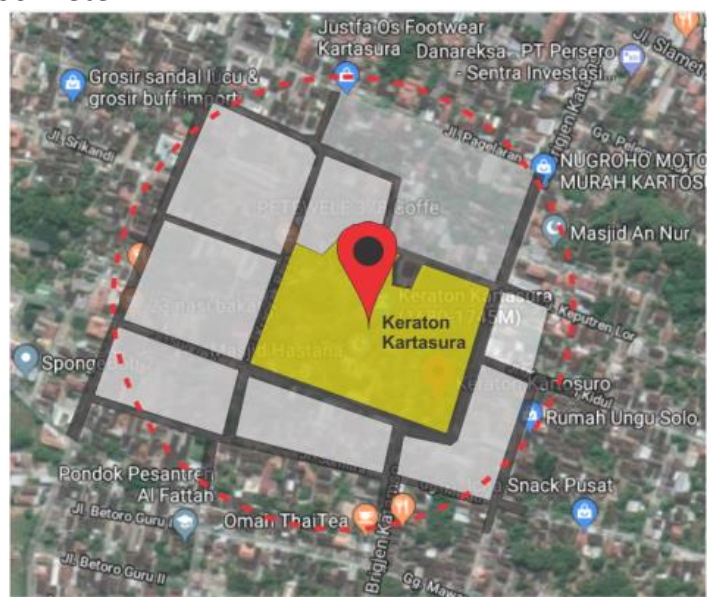

Gambar 1. Fokus Lokasi Penelitian Sumber : Analisa Penulis, 2019

\section{Observasi (Survey Lapangan)}

Lokasi penelitian yang diobservasi adalah bekas Kraton Kartasura dan kawasan sekitarnya.

\section{Studi Pustaka}

Bahan pustaka/literatur sebagai acuan penelitian mengenai bangunan sejarah yang dijadikan asset wisata. Study pustaka secara langsung dilakukan untuk mencari informasi terkait objek amatan dari salah satu komunitas sejarah di Solo sebagai pakar sejarah.

\section{Wawancara}

Peneliti melakukan sesi wawancara dengan pihakpihak terkait objek penelitian dan pakar sejarah yang memahami Keraton Kartasura.

\section{Dokumentasi}

Peneliti melakukan aktivitas pengambilan gambargambar yang berkaitan dengan permasalahan pada penelitian ini sesuai yang diperlukan sebagai bukti pendukung.

\section{Kuesioner}

Daftar kuesioner berupa beberapa pertanyaan yang kemudian dibagikan kepada pihak-pihak terkait secara langsung maupun via online.

\section{Analisa Data}

Tahap pengolahan data menggunakan tabel, grafik, dan pemetaan. Tabel bertujuan untuk mengelompokkan data-data terkait sesuai indikator yang telah ditentukan, grafik bertujuan untuk mengetahui perbandingan prosentase dari tiap indikator, sedangkan pemetaan bertujuan untuk menunjukkan titik-titik mana saja sesuai data-data yang telah diperoleh.

\section{HASIL DAN PEMBAHASAN}

\section{Hasil Wawancara}

Juru kunci Keraton Kartasura selaku narasumber menyebutkan, bahwa Keraton kartasura merupakan kerajaan Islam yang berdiri pada 11 September 1680 dan dibuat dengan tergesa-gesa dalam waktu 9 bulan, yang terdiri dari alun-alun utara dan selatan, benteng dalam sri manganti dan benteng luar baluarti, perkampungan, serta bangunan pagelaran. Benteng keraton hanya berupa batubata dikarenakan Sang Raja menginginkan kesan natural. Setelah mengalami kehancuran, Keraton Kartasura dipindahkan ke Surakarta dan pada tanggal 17 September 1745 berdirilah Keraton Surakarta, nama ini hanya kebalikan dari Kartasura.

Bangunan-bangunan yang ada berupa bangsa pasewakan, ndalem ageng, pohon beringin, meriammeriam ikut dipindahkan ke Surakarta, yang tertinggal hanya 2 benteng dengan kondisi sudah rusak, karena 
tidak adanya kepedulian terhadap warisan budaya tersebut. Setelah tidak ada bangunan, tempat ini menjadi alas keraton, disini tumbuh pohon-pohon besar, dan pohon yang tersisa saat ini hanya pohon kleco.

Tahun 1816 bekas Keraton Kartasura dibuat makam dan hanya ada 1 rumah di dalam benteng keraton. Kemudian dibuatkan kembali bangunan duplikat bangsal petilasan keraton dan masjid hastana sebagai ikon. Makam ditutup setelah ada UU cagar budaya 2010. Petilasan keratin adalah untuk wisata bukan untuk makam, namun makam yang sudah ada tetap berada pada tempatnya, bisa juga dipindahkan apabila menginginkan jika tidak dipindah harus dijaga dengan baik.

Berikut merupakan penjelasan singkat mengenai tempat-tempat terkait Keraton Kartasura:

1. Gedong Obat = makam (sekarang), tempat penyimpanan obat dan mesiu (dahulu).

2. Gedong Piring = dahulu markas VOC (sekarang MTA.)

3. Kampong Masjid = dahulu lokasi Masjid Agung Kartasura, sekarang makam yang terletak di dekat pabrik kertas.

4. Gunung Kunci = dahulu tempat segoroyoso (segoro atau danau buatan), sekarang makam dan lapangan.

Mayoritas tempat-tempat tersebut dijadikan makam karena kebijakan dari kerajaan menyebutkan bahwa: (1) agar tidak digunakan untuk membuat bangunan baru, (2) sebagai lambang matinya sebuah keraton.

Adapun aktivitas dan potensi fisik yang selama ini berlangsung, sebagai berikut:

1. Situs = benteng dikelola, dipertahankan, dibersihkan, hingga diperbaiki untuk menguri-uri aslinya atau melestarikan kondisi asli.

2. Jebolan pecinan, petilasan tempat tidur raja, bangsal, dan makam-makam kuno (dapat sebagai potensi wisata).

3. Kegiatan sosial budaya = sadranan (acara bersihbersih makam), acara kirab, bazar, panggung hiburan memperingati hari jadi Kartasura.

4. Hadrah sedah mirah dan Pertemuan PAKASA (Patilasan Keraton Kartasura).

5. Kuliner = angkringan dalam keraton.

6. Wacana Program Kerja = Car Free Day di sekitar keraton, dengan benteng Keraton Kartasura sebagai pusat utama.

Potensi tersebut menarik untuk dikembangkan, namun berdasarkan wawancara dan pengamatan, tampaknya terkendala dana.

Potensi Petilasan Keraton Kartasura dan Kawasan Sekitar Sebagai Aset Wisata Kreatif
Berdasarkan data yang diperoleh dan analisanya, ditemukan beberapa potensi asset wisata yang dapat dikembangkan:

\section{Sejarah (Situs/Benteng)}

Situs merupakan sebuah kompleks peninggalan Keraton Kartasura dimana di dalamnya terdapat dua bangunan inti yaitu Bangsal dan Masjid Keraton. Situs ini dijadikan sebagai makam kerabat keraton, namun setelah adanya larangan beberapa waktu silam maka tempat ini ditutup untuk pemakaman.

\section{Bangunan dan Lingkungan Buatan}

Bangunan yang dimaksud berupa rumah tinggal atau sejenisnya yang memiliki ciri khas/keunikan berdasar tipe bangunan jaman dahulu (tradisional Jawa). Mayoritas tipe bangunan tradisional sudah tercampur dengan gaya yang modern. Sedangkan lingkungan buatan yang dimaksud berupa open space antar bangunan rumah tinggal, belum ada upaya untuk dikembangkan.

\section{Tradisi Sosial-Budaya}

a. Tiap Malam Jum'at Kliwon

Setiap malam jum'at kliwon diadakan kegiatan hadrah di Bangsal Keraton dengan mengundang ustadz maupun kyai dari daerah tertentu.

b. Tiap Malam Jum'at Pahing

Setiap malam Jum'at pahing diadakan kegiatan Pertemuan Pakasa (Patilasan Keraton Kartasura) semacam kegiatan karawitan dan diselenggarakan di Bangsal Keraton.

\section{Tradisi rutin tiap tahun}

a. Kegiatan Sadranan

Sebuah kegiatan dimana orang-orang berkunjung untuk melakukan ziarah ke makam kerabat mereka. Kegiatan ini diadakan setiap satu tahun sekali, biasanya mendekati bulan Ramadhan (bulan puasa).

b. Kegiatan Ulang Tahun Kartasura Sebuah kegiatan dimana setiap memperingati hari jadi Kartasura diadakan berbagai kegiatan untuk memeriahkan momen tersebut. Mulai dari karnaval, bazar di sekitar benteng, hingga acara pertunjukan wayang di Bangsal Keraton.

c. Gunungan

\section{Tradisi Seni (Pertunjukan) Budaya}

Tradisi atau kegiatan seni budaya di kawasan Kartasura yang selama ini telah dipertunjukkan yaitu wayang, tari dan karnaval, yang berlangsung setiap memperingati hari jadi Kota Kartasura. Pertunjukkan wayang dipersembahkan di bangsal keraton atau pendopo dalam keraton, pertunjukkan tari 
dipentaskan di panggung yang telah disediakan di luar benteng keraton, sedangkan karnaval dilakukan di sepanjang Jalan Slamet Riyadi bagian selatan hingga finish di Keraton Kartasura.

\section{Home Industry}

Terdapat berbagai jenis home industry yang sudah berkembang di kawasan Keraton Kartasura dan sekitarnya dimana hal ini berkaitan dengan ekonomi kreatif. Jenis-jenis usaha rumahan tersebut yaitu industri makanan, industry fashion, industry pembuatan bingkai/frame.

\section{Wisata Kuliner}

Wisata kuliner ini merupakan salah satu wacana kegiatan yang juga berkaitan dengan ekonomi kreatif dan masih dalam proses untuk dikembangkan oleh pihak keraton. Sebagai gambaran, kegiatan ini nantinya dikemas dalam bentuk Car Free Day (CFD) dari gapura masuk keraton (alun-alun utara) hingga alun-alun selatan.

Table 3. Analisis Identifikasi Potensi Berdasarkan Indikator

\begin{tabular}{|c|c|c|c|}
\hline Indikator Potensi & $\begin{array}{l}\text { Jumlah } \\
\text { Potensi }\end{array}$ & $\begin{array}{l}\text { Sudah } \\
\text { Berkem } \\
\text { bang }\end{array}$ & $\begin{array}{l}\text { Belum } \\
\text { Berkem } \\
\text { bang }\end{array}$ \\
\hline Situs Bersejarah & (2) & & \\
\hline Keraton Kartasura & & $\sqrt{ }$ & \\
\hline Gedung Obat & & & $\mathrm{X}$ \\
\hline $\begin{array}{l}\text { Bangunan dan } \\
\text { Lingkungan Buatan }\end{array}$ & & $\checkmark$ & \\
\hline $\begin{array}{l}\text { Rumah Tinggal } \\
\text { Rumah Warga }\end{array}$ & (4) & & \\
\hline Rumah dan Usaha & (3) & $\mathrm{V}$ & \\
\hline Toko Fashion & (1) & 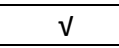 & \\
\hline Ruko-Ruko & (1) & $\sqrt{ }$ & \\
\hline $\begin{array}{l}\text { Open space antar } \\
\text { rumah }\end{array}$ & - & & $x$ \\
\hline Tradisi Sosial-Budaya & (3) & & \\
\hline Pertemuan rutin & & $\mathrm{V}$ & \\
\hline Kegiatan Sadranan & & $\mathrm{V}$ & \\
\hline Tradisi Gunungan & & V & \\
\hline $\begin{array}{l}\text { Tradisi Seni } \\
\text { (Pertunjukan) Budaya }\end{array}$ & (3) & & \\
\hline Pertunjukan Wayang & & $\mathrm{v}$ & \\
\hline Pertunjukan tari & & $\sqrt{ }$ & \\
\hline Karnaval & & $\mathrm{V}$ & \\
\hline \multicolumn{4}{|l|}{ Home Industry } \\
\hline $\begin{array}{l}\text { Industry makanan } \\
\text { (Warung Makan) }\end{array}$ & $(2)$ & $\checkmark$ & \\
\hline $\begin{array}{l}\text { Pengrajin } \\
\text { bingkai/frame }\end{array}$ & (1) & v & \\
\hline $\begin{array}{l}\text { Industry fashion } \\
\text { Wisata Kuliner }\end{array}$ & (1) & v & \\
\hline CFD & - & & $\mathrm{x}$ \\
\hline
\end{tabular}

Sumber : Analisa Penulis, 2019

Gambar 2 menunjukkan prosentase hasil potensi yang sudah berkembang sebagai berikut:
Potensi Sudah Berkembang
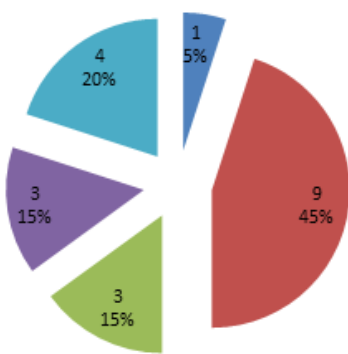

n Situs Sejarah

- Bangunan Rumah tinggal

- Tradisi Sosial Buday

- Tradisi Seni Budaya

wome Industry

Gambar 2. Hasil Data Potensi yang Sudah Berkembang (Sumber: Analisa Penulis, 2019)

1. Situs Sejarah = berjumlah 1 , dengan prosentase $5 \%$

2. Bangunan Rumah Tinggal = berjumlah 9, dengan prosentase $45 \%$

3. Tradisi Sosial Budaya dan Tradisi Seni Budaya $=$ masing-masing berjumlah 3 , dengan prosentase $15 \%$

4. Home Industry = berjumlah 4 , dengan prosentase $20 \%$

Perbandingan Potensi Sudah Berkembang dan Belum Berkembang

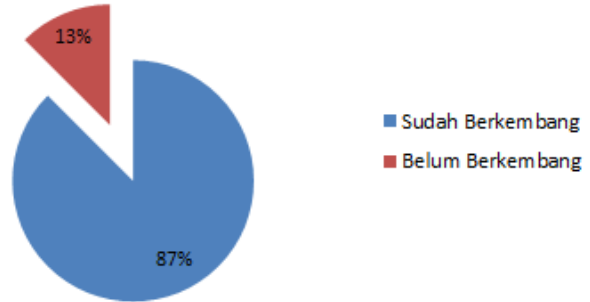

Gambar 3. Prosentase Hasil Perbandingan Potensi yang Sudah dan Belum Berkembang (Sumber: Analisa Penulis, 2019)

Gambar 3 menunjukkan prosentase kesimpulan identifikasi potensi wisata kreatif, sebagai berikut:

1. Potensi sudah berkembang $=87 \%$

2. Potensi belum berkembang $=13 \%$

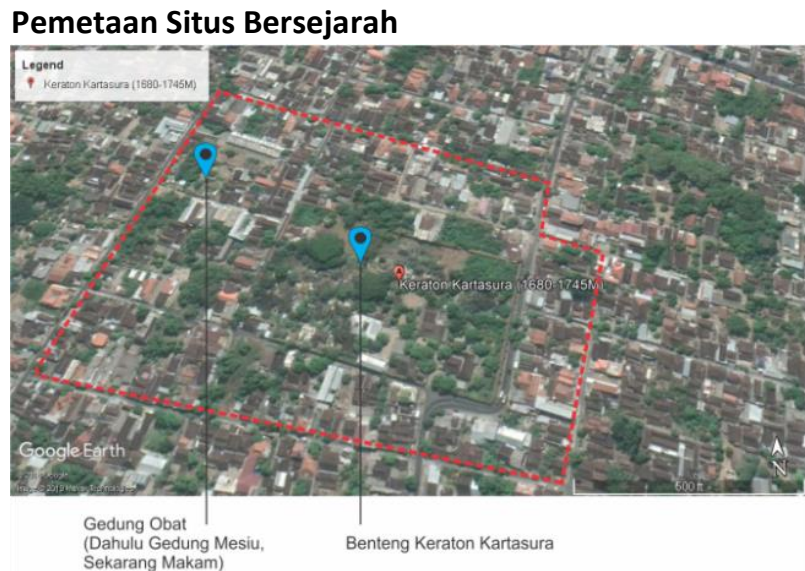

Gambar 4. Pemetaan Situs Bersejarah dalam radius $100 \mathrm{~m}$ Sumber : Analisa Penulis, 2019 
Dari Gambar 4 pemetaan situs bersejarah dapat diambil kesimpulan bahwa situs bersejarah yang terdapat di kawasan Keraton Kartasura dan sekitarnya dalam radius 100 meter, hanya berjumlah dua situs yaitu Bekas Keraton Kartasura dan Gedung Obat (dahulu sebagai gedung mesiu, sekarang makam).

\section{Pemetaan Home Industry}

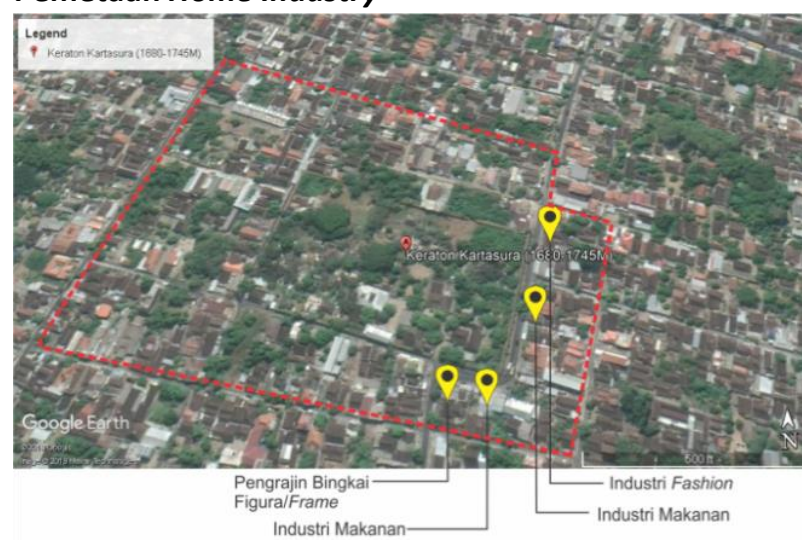

Gambar 5. Pemetaan Home Industry di Sekitar Keraton dalam radius $100 \mathrm{~m}$ (Sumber : Analisa Penulis, 2019)

Gambar 5 menunjukkan pemetaan terhadap Home Industri yang terdapat di kawasan Keraton Kartasura dan sekitarnya dalam radius 100 meter, berjumlah empat tempat yaitu industri fashion, dua industry makanan, dan pengrajin bingkai/frame figura.

\section{Pemetaan Tipe Rumah Tinggal dan Home Industry}

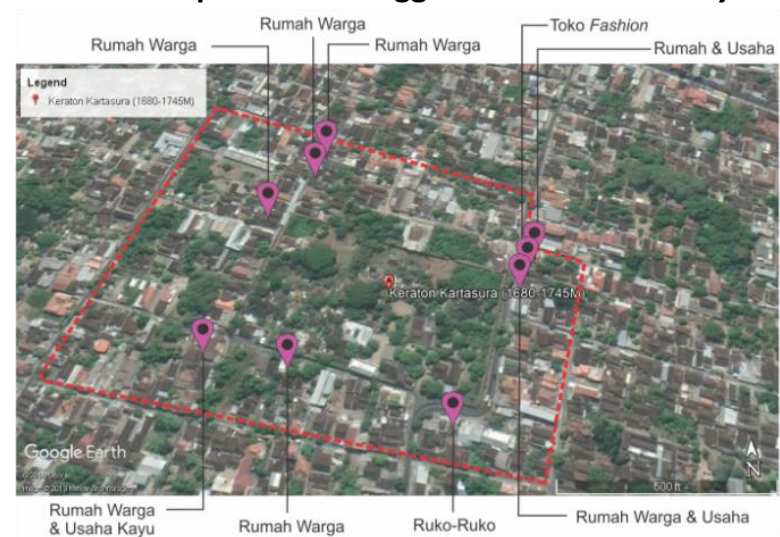

Gambar 6. Pemetaan Tipe Rumah Tinggal dan Home Industry di Sekitar Keraton dalam Radius 100 m

Sumber : Analisa Penulis, 2019

Gambar 6 pemetaan rumah tinggal dan usaha yang memiliki tipe bangunan khas jaman dahulu (tradisional Jawa) yang terdapat di kawasan Keraton Kartasura dan sekitarnya dalam radius 100 meter, berjumlah sembilan rumah yaitu empat rumah warga, tiga rumah dan usaha, satu deret ruko-ruko, serta toko fashion.

Fasilitas Pendukung Wisata (Sarana dan Prasarana)
Berikut merupakan analisa fasilitas pendukung di kawasan Keraton Kartasura dan sekitarnya sesuai konsep pariwisata 4A:

Table 4. Analisa Fasilitas Pendukung Berdasarkan Konsep $4 \mathrm{~A}$

\begin{tabular}{|c|c|c|c|}
\hline Konsep 4A & Indikator & Ada & $\begin{array}{r}\text { Tidak } \\
\text { Ada }\end{array}$ \\
\hline \multirow{4}{*}{ Atraksi } & Keindahan & & $\mathrm{V}$ \\
\hline & Budaya & $\mathrm{V}$ & \\
\hline & $\begin{array}{l}\text { Peninggalan } \\
\text { bersejarah }\end{array}$ & V & \\
\hline & $\begin{array}{l}\text { Sarana permainan } \\
\text { dan hiburan }\end{array}$ & V & \\
\hline \multirow{5}{*}{ Aksesibilitas } & $\begin{array}{l}\text { Kondisi jalan } \\
\text {-jalan utama } \\
\text {-jalan beton }\end{array}$ & $\begin{array}{l}\mathrm{V} \\
\mathrm{V}\end{array}$ & \\
\hline & $\begin{array}{l}\text { Transportasi } \\
\text {-udara }\end{array}$ & V & \\
\hline & -laut & & V \\
\hline & -darat & $\sqrt{ }$ & \\
\hline & Papan petunjuk arah & $\sqrt{ }$ & \\
\hline \multirow{11}{*}{ Amenitas } & Penginapan & $\mathrm{V}$ & \\
\hline & Gereja & $\mathrm{V}$ & \\
\hline & $\begin{array}{l}\text { Pondok setengah } \\
\text { terbuka }\end{array}$ & & V \\
\hline & Restoran/warung & $\sqrt{ }$ & \\
\hline & Tempat parker & & $\mathrm{V}$ \\
\hline & MCK & & $\mathrm{V}$ \\
\hline & Jasa angkut & & $\mathrm{V}$ \\
\hline & Jasa komunikasi & & $\mathrm{V}$ \\
\hline & Jasa pemandu wisata & & $\mathrm{V}$ \\
\hline & Pos keamanan & & $\mathrm{V}$ \\
\hline & Area pejalan kaki & V & \\
\hline \multirow{3}{*}{ Aktivitas } & Pemerintah & $\mathrm{V}$ & \\
\hline & Swasta & & $\mathrm{V}$ \\
\hline & Masyarakat & $\mathrm{V}$ & \\
\hline
\end{tabular}

Sumber : Analisa Penulis, 2019

Berdasarkan hasil temuan di lapangan sesuai indikator yang digunakan, dapat disimpulkan bahwa:

1. Dilihat dari atraksi di kawasan Keraton Kartasura dan sekitarnya sudah dapat dikatakan memenuhi syarat untuk dijadikan destinasi wisata/daerah wisata namun masih kurang dalam hal keindahan alam di sekitarnya.

2. Dilihat dari aksebilitas di kawasan Keraton Kartasura sudah tersedia namun kualitasnya minim atau bisa dikatakan belum memenuhi syarat untuk dijadikan destinasi wisata/daerah wisata.

3. Dilihat dari amenitas dapat dikatakan belum memenuhi syarat untuk dijadikan destinasi wisata atau daerah wisata, karena sangat minim adanya fasilitas pendukung.

4. Dilihat dari aktivitas belum ada pihak-pihak yang ikut berpartisipasi untuk mengembangkan kawasan Keraton Kartasura dan sekitarnya sebagai tempat wisata, namun masyarakat 
sekitar telah berupaya untuk melestarikan situs cagar budaya tersebut.

\section{Kendala Bekas Keraton Kartasura Sebagai Aset Wisata Kreatif}

Kendala utama yaitu faktor ekonomi (keuangan), dikarenakan dalam merawat situs benteng Keraton Kartasura pihak pengelola (komunitas yang peduli cagar budaya) tidak mendapatkan bantuan dana dari pemerintah. Bantuan dana yang selama ini ada hanya diperuntukkan bagi perawatan pagar benteng saja, tidak sampai pada bagian dalam beteng, yang masih terdapat bangunan dan makam. Adapun kendala lain yang menjadi penghambat yaitu faktor fasilitas pendukung wisata. Berdasarkan hasil analisa, sarana dan prasarana di sekitar kawasan Keraton Kartasura masih sangat kurang dan bisa dikatakan belum memenuhi syarat sebagai daerah tujuan wisata.

\section{KESIMPULAN}

1. Mengacu pada indikator yang digunakan dalam mengidentifikasi potensi-potensi yang sudah ada maupun belum didapat hasil prosentase, $87 \%$ potensi sudah berkembang sedangkan 13\% potensi belum dimanfaatkan. Namun, apabila dikaitkan dengan wisata kreatif dimana terdapat interaksi antara warga dengan pengunjung/ wisatawan, dari potensi-potensi yang sudah berkembang tersebut belum semua dapat dimanfaatkan secara maksimal sehingga jarang atau bahkan tidak ada wisatawan yang datang. Terkait sedikit pembahasan mengenai ekonomi kreatif, di kawasan bekas Keraton Kartasura dan sekitarnya dirasa belum ada produk-produk inovatif yang khas dari daerah tersebut. Sedangkan hasil kuesioner yang telah dibagikan, mayoritas responden mendukung apabila bekas Keraton Kartasura dan kawasan sekitarnya dijadikan sebagai tempat wisata kreatif. Hal ini akan berpengaruh terhadap arah perubahan lebih baik bagi perekonomian masyarakat.

2. Faktor penghambat belum terlaksananya wacana bekas Keraton Kartasura dan kawasan sekitar menjadi tempat wisata dikarenakan terkendala dana. Dana yang telah diberikan oleh pemerintah hanya diperuntukkan pada bagian pemeliharaan tembok bentengnya saja. Faktor lainnya yaitu terkait fasilitas pendukung wisata di sekitar kawasan keraton masih sangat minim atau bahkan belum ada.

Berdasarkan kesimpulan tersebut, maka disarankan perlu adanya program pemerintah daerah sebagai upaya untuk mengembangkan potensipotensi yang telah ada guna mendukung bangunan bersejarah bekas Keraton Kartasura dan kawasan sekitar sebagai wisata kreatif.
Kerjasama pemerintah daerah dan kesadaran masyarakat sangat perlu diupayakan untuk menyelamatkan situs cagar budaya petilasan Keraton Kartasura agar wacana untuk menjadikan tempat wisata kreatif dapat terwujud.

\section{DAFTAR PUSTAKA}

Herlina W, Irma dkk. (2016). Analisis Kebutuhan Prasarana dan Sarana Pariwisata di Danau Uter Kecamatan Aitinyo Kabupaten Maybrat Propinsis Papua Barat, Ejournal. Universitas Sam Ratulangi, Manado.

Lampah, L. (2017). Kartasoera Sebelum Soerakarta. $\mathrm{Hal}:$ 4-7.

Yoeti, Oka A. (1996). Pengantar Ilmu Pariwisata. Bandung: Angkasa.

Ooi, Can-Seng (2006). "Tourism and the Creative Economy in Singapore

Pendit, N. S. (2003). Ilmu Pariwisata Sebuah Pengantar Perdana. Jakarta: PT. Pradnya Paramitha.

Sugiyono. (2009). Metode Penelitian Pendidikan Pendekatan Kuantitatif, Kualitatif, dan R\&D. Bandung: Alfabeta.

Peraturan Pemerintah No.24 Tahun 1979

Surat Keputusan Departemen Pariwisata, Pos, dan Telekomunikasi No.KM 98/PW:102/MPPT-87

Undang-Undang Republik Indonesia Nomor 9 Tahun 1990 Tentang Kepariwisataan

Undang-Undang Republik Indonesia Nomer 11 Tahun 2010 Tentang Cagar Budaya

https://www.e-jurnal.com/2013/12/pengertiansejarah-menurut-para-ahli.html (Diakses pada 8 November 2019) 